\title{
Guarantees of independence of the Supreme Audit Institutions of the EU Member States - a comparative legal analysis ${ }^{1}$
}

\section{Gwarancje niezależności najwyższych organów kontroli w państwach członkowskich UE - analiza prawnoporównawcza}

\begin{abstract}
In the light of the standards of the International Organisation of Supreme Audit Institutions (INTOSAI) the basic principles for the functioning of the supreme audit institution should be laid down in a constitution which guarantees their stability. In this respect, it is proposed that constitutional provisions should lay down the basic principles for the functioning of supreme audit institutions, including, inter alia, the procedure for their establishment, the procedure for the appointment and dismissal of chairpersons and members of the institution

Article prepared under a grant funded by the National Science Centre (Poland) 2018/02/X/HS5/00047 - „Najwyższe organy kontroli w systemach konstytucyjnych państw członkowskich Unii Europejskiej”.
\end{abstract}


concerned, basic powers and auditing responsibilities, reporting obligations and institutional guarantees of the functional and organisational independence of the authority. This article aims to analyse the constitutional regulations of the EU Member States to guarantee the independence of Supreme Audit Institutions.

Keywords: Supreme Audit Institutions; independence of the Supreme Audit Institutions; EU Member States; state audit; INTOSAI.

Streszczenie. W świetle standardów Międzynarodowej Organizacji Najwyższych Organów Kontroli (INTOSAI) podstawowe zasady funkcjonowania najwyższego organu kontroli powinny być określone w konstytucji, która stanowi gwarancję ich stabilności. W tym zakresie postuluje się, aby przepisy konstytucyjne określały podstawowe zasady funkcjonowania najwyższych organów kontroli, w tym m.in. procedurę jego ustanowienia, procedurę powoływania i odwoływania prezesów i członków danej instytucji, podstawowe uprawnienia oraz obowiązki kontrolne, obowiązki sprawozdawcze, a także instytucjonalne gwarancje niezależności funkcjonalnej i organizacyjnej organu. Niniejszy artykuł ma na celu analizę regulacji konstytucyjnych państw członkowskich UE gwarantujących niezależność najwyższych organów kontroli.

Słowa kluczowe: najwyższe organy kontroli; niezależność najwyższych organów kontroli; państwa członkowskie UE; kontrola państwowa, INTOSAI.

\section{Introduction}

The state's supreme audit institutions (SAI) have nowadays become an indispensable element of any democracy. These bodies are usually treated in the EU Member States as the "longa manus" of parliament chambers, which is a means of enabling the chambers to exercise control over the government and public administration of the state ${ }^{2}$. By carrying out independent audits of the management of public funds and related activities of the government, government administration and other administrators of these funds, they provide parliament with information, formulate opinions on issues related to financial statements and the implementation of gov-

2 Z. Witkowski, Ustrój konstytucyjny współczesnych Włoch w aktualnej fazie jego przemian 1989-2004, Toruń 2001, p. 295. 
ernment programmes, projects and other activities. As a result, the state's supreme audit institutions are characterised not only as bodies supporting the parliament, but also the government, and they remain in a relationship of subsidiarity with these institutions, which does not exclude neutrality and objectivity in action.

However, supreme audit institutions are only able to carry out their tasks properly if they remain independent of the controlled entities and are protected from external pressure. In order to guarantee the necessary independence in the organisational, functional and financial spheres for the state's supreme audit institutions, it is necessary to adopt appropriate legal regulations and ensure a high level of state culture. Indeed, supreme audit institutions should have a stable legal basis laid down in the Constitution and laws. Constitutional provisions should therefore lay down basic principles for the functioning of supreme audit institutions, including, inter alia, the procedure for its establishment, appointment and dismissal of its chairpersons and members, basic control powers and duties, reporting obligations, as well as institutional guarantees for the independence of the body, including a clear definition of its connection with the legislative and executive powers ${ }^{3}$.

It should be emphasised that the paper adopted a definition of the supreme audit institution in a narrow sense. In this definition, which is a product of the modern idea of constitutionalism, attention is drawn to the association of the activities of the state's supreme audit authority with an independent, central body that controls public finances. It is, therefore, a legal entity that has been specially created for this purpose, which is equipped with the competence to act on behalf of the state, or a group of entities whose main, if not exclusive task is to perform the control function, including financial control in particular ${ }^{4}$.

3 Good Practices in Supporting Supreme Audit Institutions, OECD Publishing 2015, pp. 20-23, https://www.oecd.org/dac/effectiveness/Final\%20SAI\%20Good\%20Practice\%20 Note.pdf (access on-line: 14.12.2018).

4 D. Goldsworthy, Governance and Supreme Audit Institutions Reflections from the UK National Audit Office, Londyn 2016, p. 3. 
The existence of bodies appointed to perform a similar systemic function in many countries encourages an attempt to identify and characterise constitutional guarantees of independence of supreme audit institutions in the conditions in which a democratic state and free market economy function. This is not an easy task, because in the doctrine of constitutional law this issue has not yet been systematically elaborated. The aim is to limit the analysis of the issue exclusively to the EU Member States with a well-established democracy, a stable division of power and a wellestablished political and legal culture. It should be noted that in spite of the progressing integration process, control institutions in individual states have a different shape of the political system and position in the state apparatus, which result mainly from the political tradition of a given state. Therefore, it will be important to indicate the differences and similarities between political solutions adopted in individual EU Member States.

\section{INTOSAI Guidelines and Good Practices related to SAI Independence}

In the light of the provisions of the International Organisation of Supreme Audit Institutions (INTOSAI) documents under examination, the basic principles for the functioning of the supreme audit institution should be laid down in a constitution which guarantees their stability. In this respect, it is proposed that constitutional provisions should lay down basic principles for the functioning of supreme audit institutions, including, inter alia, the procedure for their establishment, the procedure for the appointment and dismissal of chairpersons and members of the institution concerned, basic powers and auditing responsibilities, reporting obligations and institutional guarantees of the functional and organisational independence of the authority. The postulate of independence also requires that the supreme audit institution should have the financial means necessary to exercise its mandate. It is also solely responsible for managing the budget and spending the funds allocated to it. Within the legal framework, the supreme audit institution should autonomously decide on the subject matter, 
timing and scope of auditing activities and reports ${ }^{5}$. The auditing tasks of the supreme audit institution should cover the entire financial management system of the state, regardless of the location of these funds. In the light of these demands, the supreme audit institution is required to exercise full external control over public sector activities by performing both regularity and performance audits. As recommended, the supreme audit institution is also empowered to present the results of the audit in an annual report to the parliament or other competent public authorities ${ }^{6}$.

It is not possible to ensure the necessary independence of the supreme audit institution without appropriate legal regulations. The independence of the supreme audit institutions, guaranteed by legislation and embedded in national constitutions, is reflected in the effective exercise of the scrutiny function by parliaments, which strengthens citizens' confidence in state institutions. In the light of the findings, it should be stressed that the supreme audit institutions of the EU Member States have taken on a different systemic structure ${ }^{7}$.

\section{Types of SAIs and SAI governance in EU Member States}

In the Latin countries, the auditing institutions take the form of judicial bodies - courts of auditors, which, in addition to their powers of control, also have jurisdictional powers. It is true that they do not represent the

5 M. Serowaniec, The Polish Supreme Audit Office in the Light of International Standards of Organization and Operation of State Audit Institutions, „Przegląd Konstytucyjny” 2019, No 1, p. 68.

6 The Lima Declaration of Guidelines on Auditing Precepts, adopted during the ninth INTOSAI Congress which took place in Lima in 1977,

http://www.intosai.org/fileadmin/downloads/downloads/4_documents/publications/eng _publications/E_Lima_Mexico_2013.pdf. See also Mexico Declaration on SAI Independence, adopted during the XIX INTOSAI Congress, which took lace in Mexico in 2007, http://www.intosai.org/fileadmin/downloads/downloads/4_documents/publications/eng _publications/E_Lima_Mexico_2013.pdf.

7 See more M. Serowaniec, Instytucjonalne gwarancje niezależności najwyższych organów kontroli państwowej [in:] M. Serowaniec, A. Bień-Kacała, A. Kustra-Rogatka (eds.), Potentia non est nisi da bonum: księga jubileuszowa dedykowana Profesorowi Zbigniewowi Witkowskiemu, Toruń 2018, pp. 663-665. 
classic justice system, but they are part of the judiciary, which is evidenced by the principle of independence, judicial immunity, acting in the form of jurisprudence (ruling on behalf of the state, application of the judicial procedure) and collegiality ${ }^{8}$. Tribunals, as functionally separate state bodies, equally distant from both the government and parliament, are of significant importance in the performance of the state's control function. However, they were explicitly qualified (on the basis of constitutional regulation) to the judiciary only in the case of the Court of Auditors of Greece and Portugal. Among this group of supreme audit institutions, a full range of regulations advocated by the INTOSAI declarations is included in the constitutions of Belgium, Greece, Portugal and Romania. Basic laws of France, Spain and Italy do not lay down the procedure for appointing and dismissing members of Tribunals in these countries. In addition, the French Constitution does not regulate the powers to carry out inspection or the obligation to report.

Within the British legal culture, the tasks of supreme audit institutions are carried out by auditors and auditors-general who do not have jurisdictional powers. In practice, the auditors-general are dependent on the parliaments which decide to follow up the conclusions of the audit. The role of the supreme audit institution for the parliament is primarily to obtain information on the use of public funds provided for in the budget by the government and to report on the use of these funds. Supreme audit institutions, similar to the British Comptroller and Auditor-General, have been set up in Ireland, Cyprus and Malta ${ }^{9}$. The Westminster model of state control also has become an inspiration for systemic solutions adopted in Denmark, Finland and Sweden. Constitutions of these countries, with the exception of Denmark and the United Kingdom, contain regulations related to legal status. They define the relationship of the supreme audit institution with the parliament, including the obligation to report, regulate

8 R. Stapenhurst, J. Titsworth, Features and Functions of Supreme Audit Institutions, The World Bank, PREM Note No 59, October 2001, pp. 1-2.

9 J. Magnet, Classification des institutions superieurs de controle financier, „Revue Francaise de Finances Publiques” 1991, No 36, p. 12. See also R. Allen, D. Tomassi, Managing Public Expenditure. A Reference Book for Transition Countries, Paris 2001, p. 342. 
the procedure for electing the chairman (the procedure for dismissal is regulated by the Irish, Cypriot and Maltese constitutions) and the main control competences. The Basic Law of Finland, on the other hand, emphasises the independence of the Office and, at the same time, its relationship with the parliament, as well as its basic control competences, including the right to request information necessary for the performance of its tasks. The Danish Constitution, on the other hand, regulates the operations of the financial controllers appointed by the parliament, whose main task is to check the annual report on public accounts, and guarantees them the right to request the necessary information and access to documents.

In other EU Member States, the audit institutions have been given the form of chambers of auditors, organised in a manner typical of administrative bodies (hierarchical structure, official dependence), but separated from the governmental structure and gradually strengthening their links with the parliament. The mandate of the supreme audit institution is usually based on the decision of the legislative body, which is also one of the main recipients of the "services" provided by audit institutions. Acting as the external auditor of executive bodies, supreme audit institutions examine and evaluate the implementation of the state's economic policy by the executive. In all countries of this group (Austria, Bulgaria, the Czech Republic, Estonia, the Netherlands, Lithuania, Luxembourg, Latvia, Germany, Poland, Slovakia, Slovenia and Hungary) the supreme audit institutions have been set up directly under constitutional regulations. The Czech and Slovak constitutions underline the independence of the auditing authority ${ }^{10}$. Basic laws of Poland, Lithuania, Estonia and Hungary determine the relationship with the parliament, including the obligation to report, the procedure for the election of the chairperson and the main control competences. The Latvian Constitution only regulates the appointment and dismissal of state auditors. Neither does the Bulgarian Constitution have a full constitutional provision concerning the Chamber of Auditors it merely states that it carries out the audit of budget implementation and

10 State Audit in the European Union, Londyn 2005, pp. 130-139. 
that it is elected by the National Assembly. The Austrian Chamber of Auditors and the Slovenian Court of Auditors also have the status of a constitutional bodies and are subject only to the provisions of constitutions and the law. Constitutions of both countries guarantee independence of their activities, regulate their basic powers of control, the appointment of the President (appeals only in the Austrian Constitution) and other members. In addition, the Austrian Constitution lays down the status and procedure for appointing Chamber's officials and auxiliary staff, as well as relations with Parliament and the obligation to report ${ }^{11}$.

\section{Constitutional guarantees of independence of the Supreme Audit Institutions of the EU Member States}

In most of the systemic solutions analysed, national constitutional and statutory regulations specify in details the procedure for appointing (electing) the superior(s) of the supreme audit institution and the possibility of his or her early dismissal. The principle of independence is also implemented through a number of constitutional and statutory institutions of a systemic, procedural and economic nature (e.g. the principle of irremovability, the privilege of jurisdiction, stabilisation of professional position) which secure the status of the controlling staff. In the light of the adopted systemic solutions, the choice of the management and members of controlling institutions is made not only with the involvement of legislative authorities (e.g. Austria, Belgium, Spain, Latvia, Poland, Romania, Slovenia, Hungary), but also with an active participation of executive authorities (e.g. Cyprus, France, Greece, Germany, Portugal, and Italy) ${ }^{12}$. However, many of the adopted structures for the appointment of the superior and members of the auditing authority with the participation of the gov-

11 J. Mazur, Główne rodzaje najwyższych organów kontroli, „Kontrola Państwowa” 2009, No 6, pp. 29-30.

12 M. Sieklucka, Status najwyższych organów kontroli krajów Unii Europejskiej w świetle postanowień Deklaracji z Limy w sprawie zasad kontroli finansów publicznych, „Kontrola Państwowa” 2008, No 2, p. 26. 
ernment or the Head of State require that the proposed candidate obtains broad support from members of the parliament. Approval by the legislature usually requires an absolute or qualified majority of the members of parliament. The independence and non-political nature of the management of the supreme state control body is also guaranteed by the direct anchoring of the principle of incompatibility on constitutional or statutory grounds, which should be treated as the implementation of the separation of powers principle in the personal aspect. The introduction of a ban on combining certain public functions is intended to guarantee the apolitical nature of the management of the supreme audit institution, and thus to ensure impartiality and objectivity in the operations of the institution.

On the other hand, the stability of staffing is ensured by the term of office principle for the President and other members. The introduction of the principle of the term of office serves to implement the principle according to which no state authority body in a democratic state under the rule of law can be completely free from taking responsibility for its actions. However, in the vast majority of systemic solutions the principle of limiting the possibility to repeat a term of office by the chairman and members of the auditing authority has been rightly adopted, as it prevents the temptation to perform tasks and to execute competences in a manner consistent with the expectations of the creative body in the hope of extending the term of office after its expiry. The independence of the supreme audit institution's management bodies is also guaranteed by formal immunity, which in the vast majority of adopted political solutions has been granted to their superiors.

The adopted systemic solutions also aim to provide the supreme audit institution with all personal, material and financial means necessary for the performance of its tasks. In most of the analysed cases, their budget is decided directly by the parliament (e.g. the Czech Republic, Spain, Lithuania, Luxembourg, Malta, Germany, and Slovenia). On the other hand, in the event of the executive intervention, auditing authorities have the right to ask the parliament for additional funding if they consider their budgets insufficient to fulfil their tasks (e.g. Cyprus, Ireland, the Netherlands, and Italy). In the light of the applicable regulations, the draft budget of the supreme audit institution, 
adopted by the management of the auditing authority, is directly included in the draft state budget. They, too, bear sole responsibility for the management of the budget and the spending of the funds allocated to them.

Within the framework of functional independence, most of the supreme audit institutions of the EU Member States have the right to control the use of public funds, resources or assets by the recipient, regardless of its legal status. Moreover, auditing tasks cover the entire system of managing state finances regardless of the location of these resources and public operations and the fact that they are included in or excluded from the state budget. In the subjective aspect, the scope of a state control covers not only activities of government administration bodies, a state legal persons and other state organisational units, but also activities of local government bodies and self-government legal persons. As far as the objective aspect is concerned, all elements of managing public finances are subject to a state control, regardless of whether and how they are included in the general state budget. All EU Member States' auditing institutions carry out regularity audits, which, together with examining the documentation concerning a series of transactions, form the basis for the auditing authority to prepare an opinion on state accounts. That opinion constitutes a basis for the parliament to grant a discharge or to issue an opinion. With the exception of the Greek Court of Auditors, the auditing authorities also carry out performance audits to examine the economy and efficiency of the use of resources and the effectiveness of the operation and achievement of the objectives in the audited unit. In practice, most supreme audit institutions carry out comprehensive audits which take into account both the elements of regularity and performance control. Supreme audit institutions of EU Member States are also independent in drawing up the annual audit plan. In the light of the adopted systemic arrangements, supreme audit institutions of the EU Member States have been obligated to submit annual activity reports and key audit reports to parliaments, and sometimes also to other national authorities. In particular, the report on auditing the implementation of a state budget, as well as audits carried out at the request of parliaments ${ }^{13}$.

13 I. Sierpowska, Funkcje kontroli państwowej. Studium prawno-porównawcze, Wrocław 2003, pp. 154-159. 


\section{Conclusions}

The systemic solutions adopted in individual EU Member States provide the supreme audit institutions with the necessary degree of independence to make the principle of accountability of the government and other entities for the proper and effective use of public funds a reality. However, as practice shows, even complex constitutional and statutory provisions do not fully protect the independence of the state's supreme audit institution.

There are cases of interpreting regulations in force in a different way than it would stem from the intentions of their authors. Attempts have also been made to introduce new regulations to make it easier for the supreme state audit authority to become dependent on political influence. They were mainly related to various policy initiatives which aimed at introducing significant changes in the status of the state's supreme audit institution.

There is no doubt that the principle of independence of audit institutions is also adversely affected by any change in legislation that introduces or facilitates the dependence of management on political influence. The practice of the parliament rejecting the proposals of the head of the audit body regarding the selection (appointment) of members of audit institutions for non-statutory reasons, or making approval conditional on the submission of candidates from among politicians of a particular party may prove to be equally dangerous. The cases of reductions in the budget of the supreme audit institution, with the emphasis on the fact that funds have been deducted for specific tasks previously planned by the supreme audit institution, or the imposition of new tasks on the audit institution without the allocation of additional funds are certainly also worrying. Any attempt by the parliament or other state bodies to influence the results of the audit also contributes to weakening the authority of the auditing institutions ${ }^{14}$.

14 See more M. Serowaniec, Konstytucyjne gwarancje niezależności najwyższych organów kontroli państw członkowskich UE, Toruń 2018, pp. 291-297. 
Maciej Serowaniec

\section{Bibliography:}

Allen R., Tomassi D., Managing Public Expenditure. A Reference Book for Transition Countries, OECD, SIGMA, Paryż 2001.

Goldsworthy D., Governance and Supreme Audit Institutions Reflections from the UK National Audit Office, National Audit Office, Londyn 2016.

Good Practices in Supporting Supreme Audit Institutions, OECD Publishing 2015, https://www.oecd.org/dac/effectiveness/Final\%20SAI\%20Good\%20Practice \%20Note.pdf (access on-line: 14.05.2019).

Magnet J., Classification des institutions superieurs de controle financier, „Revue Francaise de Finances Publiques” 1991, No 36, p. 12.

Mazur J., Główne rodzaje najwyższych organów kontroli, „Kontrola Państwowa” 2009, No 6, pp. 28-45.

Serowaniec M., Instytucjonalne gwarancje niezależności najwyższych organów kontroli państwowej [in:] M. Serowaniec, A. Bień-Kacała, A. Kustra-Rogatka (eds.), Potentia non est nisi da bonum: księga jubileuszowa dedykowana Profesorowi Zbigniewowi Witkowskiemu, TNOiK, Toruń 2018.

Serowaniec M., Konstytucyjne gwarancje niezależności najwyższych organów kontroli państw członkowskich UE, TNOiK, Toruń 2018.

Serowaniec M., The Polish Supreme Audit Office in the Light of International Standards of Organization and Operation of State Audit Institutions, „Przegląd Konstytucyjny” 2019, No 1, pp. 68-82.

Sieklucka M., Status najwyższych organów kontroli krajów Unii Europejskiej w świetle postanowień Deklaracji z Limy w sprawie zasad kontroli finansów publicznych, „Kontrola Państwowa” 2008, No 2, pp. 25-42.

Sierpowska I., Funkcje kontroli państwowej. Studium prawno-porównawcze, Kolonia Limited, Wrocław 2003.

Stapenhurst R., Titsworth J., Features and Functions of Supreme Audit Institutions, The World Bank, PREM Note No 59, October 2001.

Witkowski Z., Ustrój konstytucyjny współczesnych Włoch w aktualnej fazie jego przemian 1989-2004, Wydawnictwo Uniwersytetu Mikołaja Kopernika, Toruń 2001. 